\title{
ENVIRONMENTAL RESEARCH LETTERS
}

LETTER • OPEN ACCESS

Labrador Slope Water connects the subarctic with the Gulf Stream

To cite this article: A L New et al 2021 Environ. Res. Lett. 16084019

View the article online for updates and enhancements. 


\title{
ENVIRONMENTAL RESEARCH
}

\section{LETTERS}

\section{LETTER}

CrossMark

\section{Labrador Slope Water connects the subarctic with the Gulf Stream}

RECEIVED

3 March 2021

REVISED

23 June 2021

ACCEPTED FOR PUBLICATION

8 July 2021

PUBLISHED

28 July 2021

Original content from

this work may be used

under the terms of the

Creative Commons

Attribution 4.0 licence.

Any further distribution

of this work must

maintain attribution to

the author(s) and the title

of the work, journal

citation and DOI.

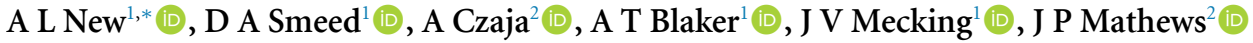 \\ and A Sanchez-Franks ${ }^{1}$ [D \\ 1 National Oceanography Centre, European Way, Southampton SO14 3ZH, United Kingdom \\ 2 Imperial College, Department of Physics, Prince Consort Road, London SW7 2AZ, United Kingdom \\ * Author to whom any correspondence should be addressed. \\ E-mail: A.New@noc.ac.uk
}

Keywords: Labrador Slope Water, Slope Sea, Gulf Stream, Atlantic Meridional Overturning Circulation, climate variability Supplementary material for this article is available online

\begin{abstract}
Labrador Slope Water (LSLW) is a relatively fresh and cool water mass that originates from the Labrador Current in the subarctic and is known to occur in the Eastern Slope Sea on the US-Canadian shelf-slope north of the Gulf Stream. It has potential densities of $27.4-27.65 \mathrm{~kg} \mathrm{~m}^{-3}$. Using ocean observations, we show here that the LSLW penetrates as a boundary current deeply into the Western Slope Sea (west of $66^{\circ} \mathrm{W}$ ) as a salinity minimum between 400 and $600 \mathrm{~m}$, bringing it into close proximity with the Gulf Stream. The LSLW at Line W (near $69^{\circ} \mathrm{W}$ ) also spreads across, and brings fresher and thicker waters to, the Slope Sea north of the Gulf Stream. A high-resolution ocean model simulation shows that the spreading of the LSLW occurs throughout the entire Slope Sea through the extrusion of fine-scale filaments from the boundary current following interaction with Gulf Stream meanders and eddies. At Line W, the LSLW is also found to be fresher and thicker between 2003 and 2008, when the Atlantic Meridional Overturning Circulation (AMOC) at $26^{\circ} \mathrm{N}$ is higher (by $3 \mathrm{~Sv}$ ), and the Shelf Slope Front is further south (by $0.7^{\circ}$ ), compared to AMOC low conditions in 2009-2014. The thicker LSLW causes lighter isopycnals to rise over the shelf slope, and through increasing the lateral density gradient contributes an additional $1.3 \mathrm{~Sv}$ to the Gulf Stream transport. These changes to the LSLW and the Shelf Slope Front are likely to result from an enhanced flow of the Labrador Current into the Slope Sea, caused by changes in the wind stress in the subpolar gyre. The transport of the LSLW (as opposed to the deeper Labrador Sea Water) thereby offers a potential new mechanism for decadal variability in the Atlantic climate system, through connecting changes in the subarctic with subsequent variability in the Gulf Stream and AMOC.
\end{abstract}

\section{Introduction}

The Atlantic Meridional Overturning Circulation (AMOC) carries warm, salty near-surface waters northwards, a major component of this being the Gulf Stream, and cooler, fresher deeper waters southwards, particularly in the Deep Western Boundary Current (DWBC), the whole being a key component of the climate system (e.g. Smeed et al 2018). As such, it is critical to better understand the mechanisms that regulate its variability.

The Slope Sea (figure 1) is found between the Gulf Stream and the shelf-slope west of the Tail of the Grand Banks (TGB). The upper waters of the Eastern Slope Sea $\left(52-66^{\circ} \mathrm{W}\right)$ consist of Warm Slope Water in the upper $300 \mathrm{~m}$ immediately north of the Gulf Stream and overlying North Atlantic Central Water, and the fresher Labrador Slope Water (LSLW) near the shelf slope (Gatien 1976, Fratantoni and Pickart 2007). The LSLW has a core potential density (referenced to the surface, $\sigma_{0}$, used throughout the present study) near $27.5 \mathrm{~kg} \mathrm{~m}^{-3}$, and at $65^{\circ} \mathrm{W}$ is centred between 400 and $800 \mathrm{~m}$, below the even fresher Coastal Water in the upper 50-100 m. The Coastal Water extends from the shelf into the Slope Sea, and the boundary between it and the Warm Slope 


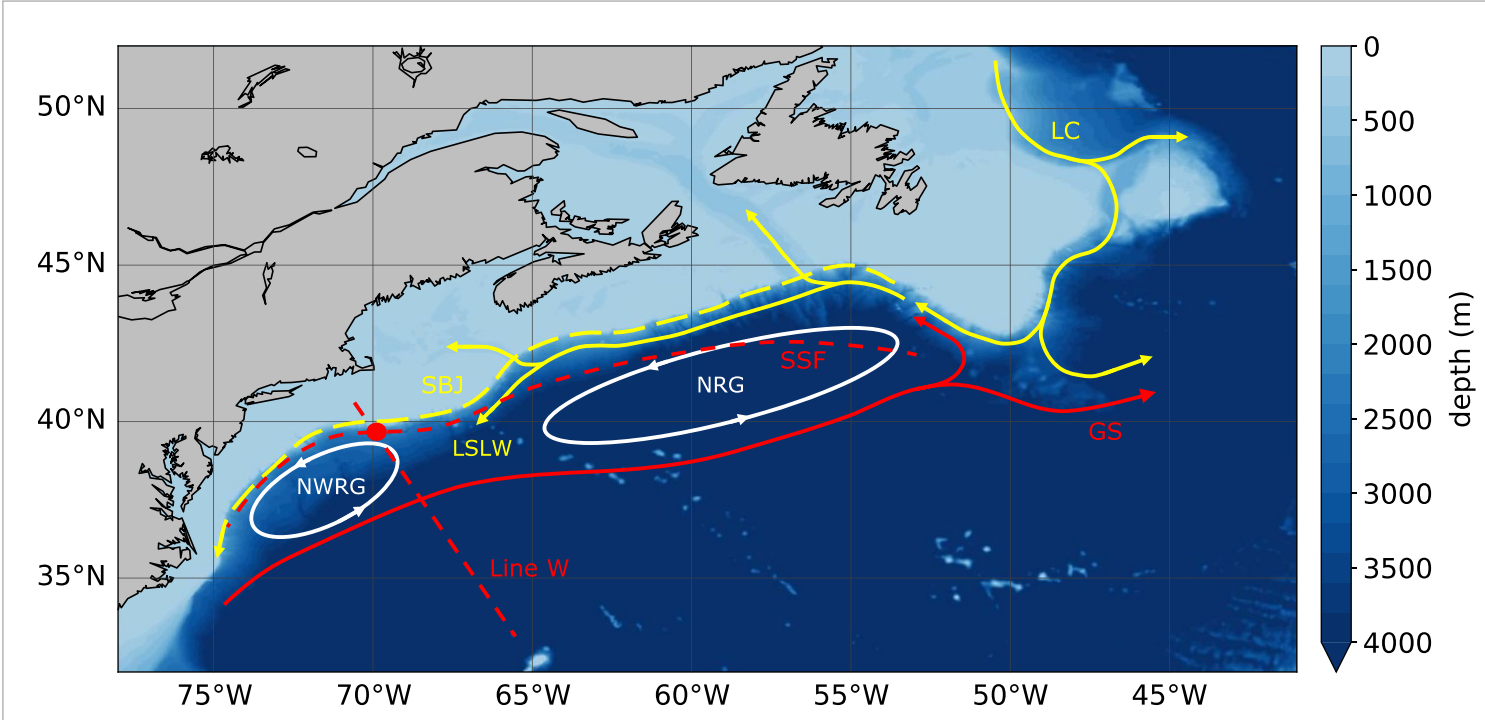

Figure 1. Circulation schematic of the Slope Sea (the region between the Gulf Stream and the shelf slope between 52 and $75^{\circ} \mathrm{W}$ ), showing the Labrador Current (LC), Labrador Slope Water (LSLW), the Shelf Break Jet (SBJ), the Gulf Stream (GS), Line W (dashed red) and Station 7 (red circle), the Northern Recirculation Gyre (NRG), the North-West Recirculation Gyre (NWRG) and the Shelf Slope Front (SSF). The ocean bathymetry is taken from the ETOPO1 dataset.

Water denotes the Shelf-Slope Front (Peterson et al 2017). The Warm Slope Water flows eastwards with the Gulf Stream, while the LSLW moves westward along the slope (Gatien 1976). This circulation may be viewed as a component of the Northern Recirculation Gyre (Hogg et al 1986), a barotropic cyclonic cell in the Eastern Slope Sea. A pronounced cyclonic cell is also found in the Western Slope Sea $\left(66-75^{\circ} \mathrm{W}\right)$, which we here call the North-West Recirculation Gyre (Csanady and Hamilton 1988, Andres et al 2020).

The LSLW derives its (cold, fresh) core properties from the Labrador Current in the subarctic region of the Labrador Sea. The Labrador Current system has an inshore branch exiting the Hudson Strait (which flows over the Grand Banks and continues as the Nova Scotia Current, Rossby 1999, Townsend et al 2015) and a further core (the LC) on the upper Labrador shelf-slope, comprising waters from the Davis Strait and (slightly more saline) the West Greenland Current (Florindo-López et al 2020). The LC flows southwards and partially rounds the TGB into the Slope Sea (figure 1), where it continues as the Shelf Break Jet, or Labrador Current Extension, in the upper $200 \mathrm{~m}$, through the entire Western Slope Sea (Flagg et al 2006, Fratantoni and Pickart 2007). The inflowing LC water also mixes with the (warmer and more saline) North Atlantic Central Water and forms the origins of the LSLW in the Slope Sea (Gatien 1976, Petrie and Drinkwater 1993). The LSLW is thereby distinct from the deeper Labrador Sea Water (LSW), which instead forms through open ocean convection in the subpolar gyre (McCartney and Talley 1982).

Below the LSLW in the Slope Sea, the DWBC carries the LSW (with neutral densities greater than $27.8 \mathrm{~kg} \mathrm{~m}^{-3}$, equivalent to $\sigma_{0}$ greater than $27.68 \mathrm{~kg} \mathrm{~m}^{-3}$ ) and deeper waters westwards (e.g.
Talley and McCartney 1982). Indeed, Csanady and Hamilton (1988) describe the circulation of the deeper waters in the Slope Sea (below $500 \mathrm{~m}$ and colder than $6{ }^{\circ} \mathrm{C}$ ) as a southwestward flow as far as the Gulf Stream, labelling this as Labrador Basin Water. Through reference to Richardson (1977), McCartney and Talley (1982), and Talley and McCartney (1982), it is clear that this is essentially the LSW. However, Richardson (1977) shows a section at Cape Hatteras in which there is a minimum in the salinity anomaly (when compared with mean western North Atlantic conditions) on the slopes between 400 and $1000 \mathrm{~m}$ which could indicate the presence of the LSLW here as well as the LSW, although this was not made explicit. Finally, the DWBC has traditionally been thought of as a continuous boundary current from the subpolar gyre, and the main conduit for the AMOC southward return flow (Watts 1991, Joyce et al 2005, Gary et al 2011, Peña-Molino et al 2011). However, recent float and tracer studies (Bower et al 2009, 2011, Smith et al 2016) and modelling investigations (Gary et al 2011) have challenged this view, showing instead the importance of an interior route through the Newfoundland Basin for these waters.

Freshening, cooling and an increased prevalence of LSLW in the Eastern Slope Sea would be expected to result from an enhanced flow of the LC into the Slope Sea (Petrie and Drinkwater 1993). This in turn may result from a high AMOC, which could be associated with increased DWBC transport and vortex stretching near the TGB, leading to a strengthening and expansion of the Northern Recirculation Gyre and a more southerly Gulf Stream in the Eastern Slope Sea (Zhang and Vallis 2007). This may then lead to freshening of the LSLW in the bottom waters 
of the Laurentian Channel, the Scotian Shelf and the Gulf of Maine (Saba et al 2016, Thibodeau et al 2018) and higher levels of nutrients and oxygen in the near surface waters (Sanchez-Franks and Zhang 2015, Claret et al 2018). Alternatively, larger inflows of the LC may result from a southward shift of wind stress patterns in the subpolar gyre, again resulting in cooling and freshening in the Eastern Slope Sea (Peterson et al 2017, Holliday et al 2020). An increasing proportion of LSLW in the Gulf of Maine may also result from decreases in either the Nova Scotia Current (Townsend et al 2015) or a shift from a positive to a negative phase of the North Atlantic Oscillation (NAO, Mountain 2012). This latter relationship is supported by Marsh (2000), who forced a $1^{\circ}$ ocean model with extreme negative NAO conditions (in which the Icelandic Low was typically further to the southwest), resulting in the subpolar gyre expanding to the south, which in turn allowed an enhanced flow of Labrador Current waters westwards from the Grand Banks, and cooling in the Eastern Slope Sea.

Consequently, while the focus of the above studies has been on the Eastern Slope Sea, the presence of the LSLW in the Western Slope Sea has so far been largely undocumented. We therefore examine here the penetration of the LSLW into the Western Slope Sea, how its characteristics change between recent AMOC high and low periods, and its impact on the Gulf Stream.

\section{Methods and data}

We use the EN4.2.1 dataset, which provides monthly gridded objective analyses of available ocean observations at $1^{\circ}$ resolution (Good et al 2013). Profiles with density inversions which are thought to be spurious and related to anomalously cold water at $657 \mathrm{~m}$ are removed from our analysis. Furthermore, EN4 profiles are derived through averaging on constant depth levels, and are subject to biases similar to those reported by Lozier et al (1994) in the Levitus climatology (Levitus 1982). These biases are largest in frontal regions where the isopycnals slope steeply such as the Gulf Stream, and result in water which is too warm and saline on intermediate-depth isopycnals. However, while EN4 cannot therefore be used for isopycnal analysis in the Gulf Stream core, it may be employed to examine the mean structure of the LSLW along the shelf slope where the isopycnals are relatively flat. These issues are described more fully in the supplementary material (available online at stacks.iop.org/ERL/16/084019/mmedia).

We also use the Line $\mathrm{W}$ hydrographic observations near $69^{\circ} \mathrm{W}$ (e.g. Joyce et al 2005). The Line passes through the Western Slope Sea, extending from Cape Cod towards Bermuda (figure 1), and provides full-depth high-quality hydrographic observations at fixed station positions between 1994 and 2014. Here, we employ water mass analysis, commonly used in oceanography, that is, examination of the relationship of the temperature $(\mathrm{T})$ and salinity (S) of various water masses. Water masses form with different temperature and salinity in different parts of the ocean surface through interaction with atmospheric fluxes. These water masses are then drawn down into the ocean interior, recirculating over large distances. Here, since mixing is generally low, they tend to maintain their T/S properties quite well as they recirculate. Therefore, they can be easily distinguished in diagrams plotting their temperature against their salinity, usually by either minima or maxima in one or other of these properties.

We also undertake analysis of the ERA5 monthlyaveraged wind stress fields (Hersbach et al 2019), which provides an updated version of the ERAinterim fields, and with increased horizontal resolution $\left(0.25^{\circ}\right.$ rather than approximately $\left.0.75^{\circ}\right)$.

Finally, we employ a global simulation with the NEMO (v3.2) ocean model (Madec 2008). With a horizontal resolution of $1 / 12^{\circ}$ and 75 levels in the vertical, the model resolves the details of the flow in the Slope Sea. Realistic bottom topography is interpolated from ETOPO2 (U.S. Department of Commerce 2006) and surface forcing is provided by DFS4.1 (Brodeau et al 2010). The simulation starts from rest and January climatological initial conditions for temperature and salinity, which are provided by the World Ocean Atlas 2005 (Antonov et al 2006, Locarnini et al 2006). This simulation shows a good representation of features that are important for this study, such as the subpolar gyre and the Gulf Stream (Marzocchi et al 2015).

\section{Westward penetration}

The mean intermediate-depth water column salinity structure in EN4.2.1 is now examined between September 2003 and August 2015 (a whole number of years to remove any seasonal bias). Figure 2(a) shows the salinity at $541 \mathrm{~m}$, this being close to the depth of the core of the LSLW. The fresh LSLW (with salinity below 35.2 and density near $27.6 \mathrm{~kg} \mathrm{~m}^{-3}$ ) extends as a boundary current around the TGB and into the Western Slope Sea as far as Cape Hatteras. It also spreads southwards as far as the centre of the Gulf Stream over the entire Slope Sea (e.g. the fresher waters extending southwards to the $27.2 \mathrm{~kg} \mathrm{~m}^{-3}$ isopycnal).

At $52^{\circ} \mathrm{W}$, the LC appears as the broad $\left(2^{\circ}\right.$ wide $)$ fresh region nearest the slope and extending to $600 \mathrm{~m}$ with salinities below 34.9 and densities less than $27.65 \mathrm{~kg} \mathrm{~m}^{-3}$ (figure 2(b)). This structure is similar to that at $46^{\circ} \mathrm{N}$ before the LC has rounded the TGB (though extending only to $300 \mathrm{~m}$ there) and at $57^{\circ} \mathrm{W}$ near the Laurentian Channel (not shown). Further west, the LSLW at $62^{\circ} \mathrm{W}$ (figure $2(\mathrm{c})$ ) appears as a distinct low salinity core between 400 and $600 \mathrm{~m}$ above the shelf slope (marked by the red star at $43^{\circ} \mathrm{N}$ ), and with densities of $27.4-27.65 \mathrm{~kg} \mathrm{~m}^{-3}$, but 


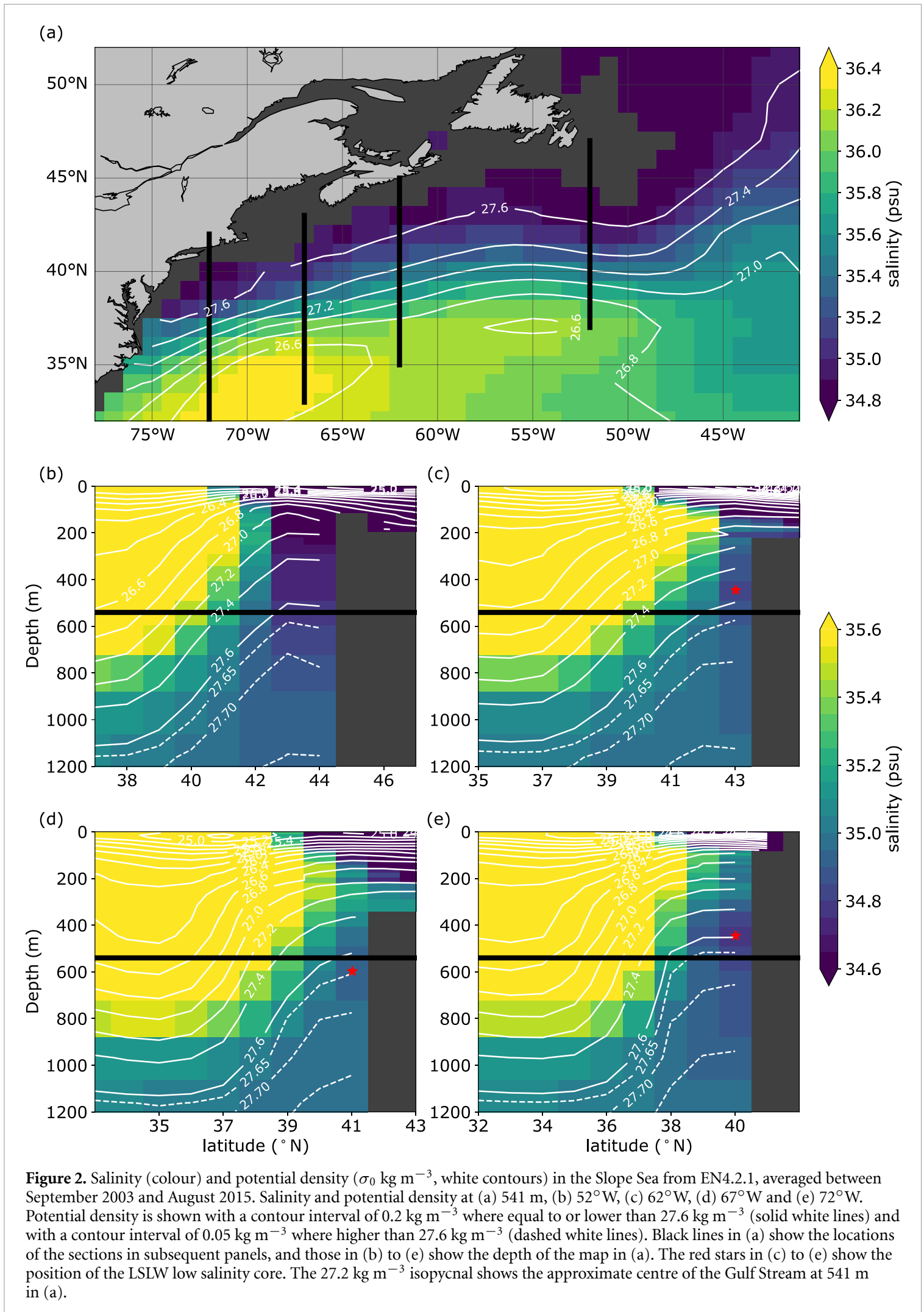

is here only $1^{\circ}$ wide. The Warm Slope Water is indicated by the yellow colours immediately to the south in the upper 300-400 $\mathrm{m}$, and the Coastal Water by the freshest waters in the upper $100 \mathrm{~m}$ above the shelf and slope. The structure is similar at 67 and $72^{\circ} \mathrm{W}$ (figures $2(\mathrm{~d})$ and (e)), with an easily identifiable LSLW salinity minimum, clearly showing that the
LSLW has penetrated deeply into the Western Slope Sea.

\section{Variability and links to the AMOC}

We now discuss the Line $\mathrm{W}$ observations between September 2003 and August 2014. By analogy with 
(a)

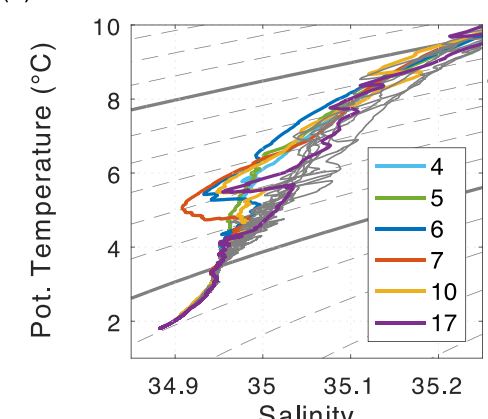

(c)

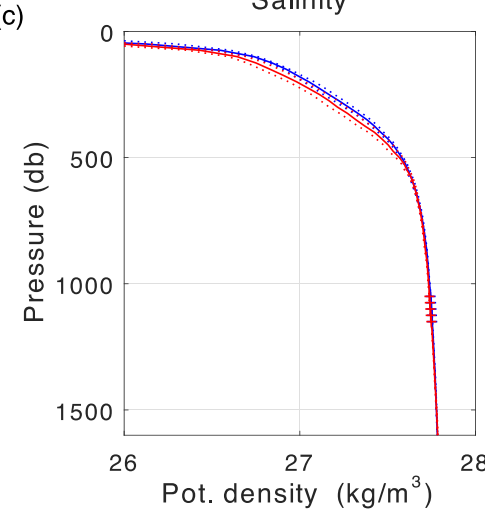

(b)

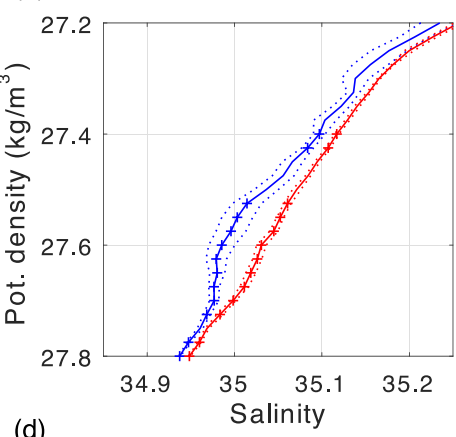

(e)

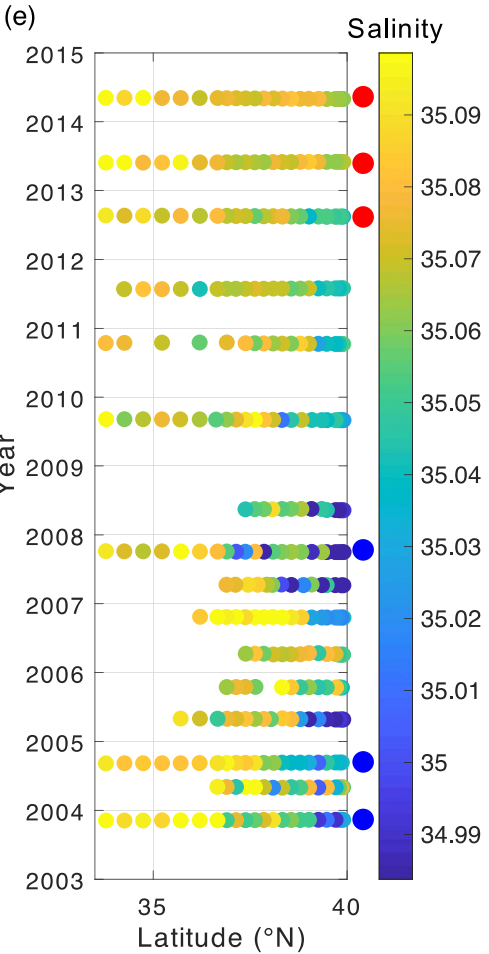

Figure 3. Hydrographic data from Line W. (a) Potential temperature versus salinity for the May 2008 occupation, and stations 4-17 (see figure 4(a) for station positions). Individual station profiles are shown by the coloured contours as indicated in the inset. Potential density contours are also shown in increments of $0.1 \mathrm{~kg} \mathrm{~m}^{-3}$, with the 27.2 and $27.8 \mathrm{~kg} \mathrm{~m}^{-3}$ contours shown by the thick continuous lines. (b) Potential density versus salinity at Station 7 and averaged over all occupations during the AMOC high period (blue) and the AMOC low period (red). Standard errors of the means are shown by the dotted lines and crosses indicate where the difference between the two periods is significant ( $95 \%$ confidence). (c) Similar to (b) but showing pressure (decibars, db, approximately equal to depth in $\mathrm{m}$ ) versus potential density. (d) Geostrophic transport change at Station 7 (integrated upwards from $2000 \mathrm{~m}$, and plotted against db) inferred from the profiles in the two periods chosen in panel (c), showing the mean and standard error. (e) Salinity on the potential density surface $27.55 \mathrm{~kg} \mathrm{~m}^{-3}$ as a function of latitude and time (showing all occupations between 1 January 2003 and 31 December 2014, and all stations from Station 4 seawards). The blue circles show the three 'fresh' (between 2003 and 2008), and the red circles the three 'salty' (between 2009 and 2014), occupations chosen for further analysis.

Smeed et al (2018), who reported a reduction in the AMOC of about $3 \mathrm{~Sv}\left(1 \mathrm{~Sv}=10^{6} \mathrm{~m}^{3} \mathrm{~s}^{-1}\right)$ as measured by the RAPID array at $26^{\circ} \mathrm{N}$ from 2008, we refer to September 2003-August 2008 as the AMOC high period, and to September 2008-August 2014 as the AMOC low, these being complete numbers of years to reduce seasonal biases. With reference to figure 3(e), which shows when the occupations occur, we consider these periods to represent 2003-2008 and 2009-2014 respectively.

Figure 3(a) presents the Temperature/Salinity curves from stations 4-17 (which extend seaward from the shelf break with increasing station number, see figure 4(a)) for the May 2008 survey. The LSLW is the salinity minima between temperatures of $4.5^{\circ} \mathrm{C}$ and $7{ }^{\circ} \mathrm{C}$ and densities of 27.4 and $27.65 \mathrm{~kg} \mathrm{~m}^{-3}$. This occurs in stations 4-7 on the upper slopes, being most pronounced at station 7 , where the water depth is about $2000 \mathrm{~m}$. It is then absent in stations 8 and 9 but, surprisingly, re-appears at both stations 10 and 17 but not at the intervening stations. At station 17, the LSLW penetrates deeply (to near $1000 \mathrm{~m}$, see figure $4(\mathrm{a})$ ) and occurs underneath and southwards of the centre of the Gulf Stream. The LSLW therefore appears primarily as a boundary current (supported by Toole et al 2011) with a core at station 7, but also occurs intermittently across the entire NorthWest Recirculation Gyre.

Figure 3(b) shows the mean salinity at station 7 during the AMOC high and low periods. The LSLW salinity minimum is only found in occupations during the AMOC high period (though not in every occupation), but is not found at all during the AMOC low period. This results in the low salinity bulge near $27.55 \mathrm{~kg} \mathrm{~m}^{-3}$ in the AMOC high period, which is absent in the AMOC low. We therefore define the LSLW to be centred on the $27.55 \mathrm{~kg} \mathrm{~m}^{-3}$ isopycnal, but to occupy densities between 27.4 and $27.65 \mathrm{~kg} \mathrm{~m}^{-3}$ (which also avoids overlap with the LSW).

This LSLW is also thicker at station 7 in the AMOC high period (see figure 4) and this results in the uplift of all isopycnals above the LSLW core, figure 3(c). The geostrophic transport calculated between the density profiles in the AMOC high and low periods will be the same as the transport difference between each profile and some arbitrary profile 
(a)

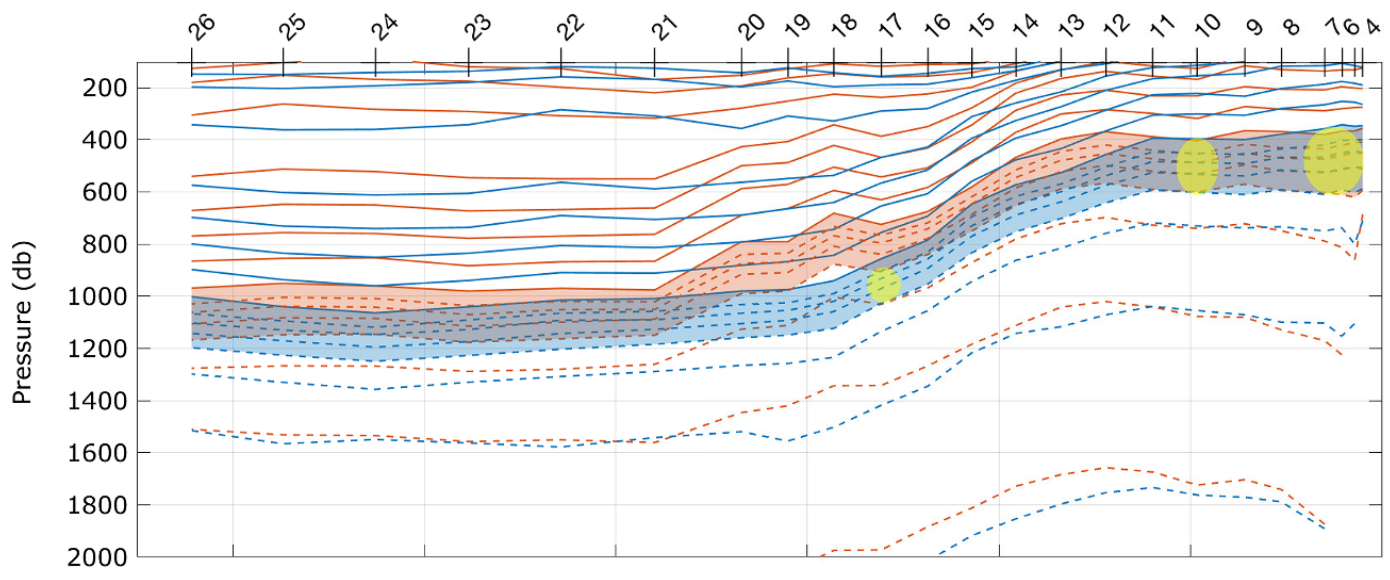

(b)

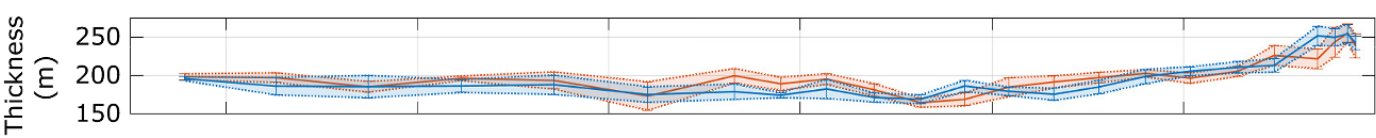

(c)

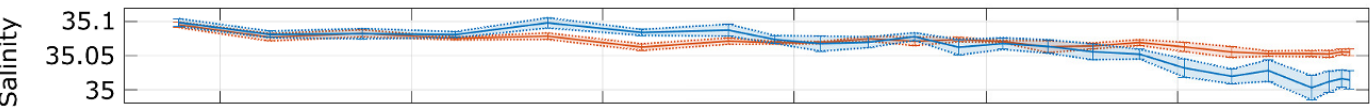

(d)

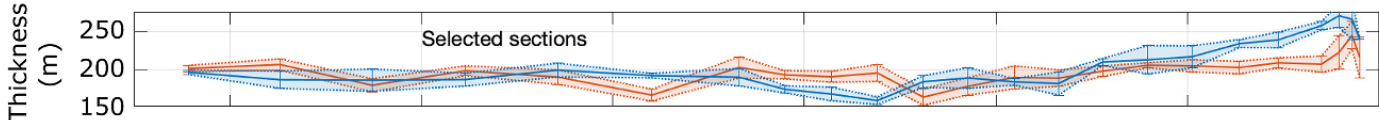

(e)

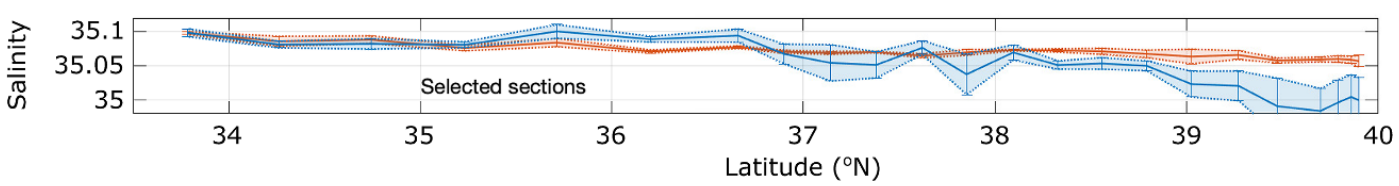

Figure 4. (a) Density sections (plotted against depth in $\mathrm{db}$ ) on Line $\mathrm{W}$ (constructed from the mean depths of the isopycnals) in the AMOC high (blue) and low (red) periods between stations 4 and 26, with the LSLW layer (between densities 27.4 and $27.65 \mathrm{~kg} \mathrm{~m}^{-3}$ ) shown shaded. Contours are shown every $0.2 \mathrm{~kg} \mathrm{~m}^{-3}$ from and lower than $27.4 \mathrm{~kg} \mathrm{~m}^{-3}$ (solid lines), and every $0.05 \mathrm{~kg} \mathrm{~m}^{-3}$ from and higher than $27.5 \mathrm{~kg} \mathrm{~m}^{-3}$ (dashed lines). Station positions are indicated at the top of the panel and yellow ovals show the occurrence of the freshest LSLW in the May 2008 occupation, overlaid on the density structure in the AMOC high period. (b) Thickness (m) of the LSLW layer in the AMOC high (blue) and low (red) periods, showing the mean and standard error of the mean. (c) Salinity on the $27.55 \mathrm{~kg} \mathrm{~m}^{-3}$ isopycnal in the AMOC high (blue) and low (red) periods, showing the mean and standard error of the mean. Panels (d) and (e) are similar to (b) and (c) respectively, but use averages over the selected full-length 'fresh' (November 2003, September 2004, and October 2007, in blue) and 'salty' (August 2012, May 2013, and May 2014 , in red) sections as indicated in figure $3(\mathrm{e})$.

on the southern side of the Gulf Stream, and so will give the transport change across the Gulf Stream due to the changes at station 7 . The result of this calculation, integrated upwards from $2000 \mathrm{~m}$, figure 3(d), shows that this contributes an increase of $1.3 \mathrm{~Sv}$ in Gulf Stream transport (i.e the change above $600 \mathrm{~m}$ ), nearly half of the AMOC change reported by Smeed et al (2018) at $26^{\circ} \mathrm{N}$. While the role of the DWBC waters cannot be entirely discounted, note that the transport change below $600 \mathrm{~m}$ is relatively small.

Figure $3(\mathrm{e})$ shows the salinity on the $27.55 \mathrm{~kg} \mathrm{~m}^{-3}$ isopycnal for every occupation in our time window. The LSLW is generally fresher north of the Gulf Stream core (near $37.7^{\circ} \mathrm{N}$, figure 4 ), and is freshest nearest the shelf $\left(39-40^{\circ} \mathrm{N}\right)$. There is also a striking change from 2008, between fresher varieties during the AMOC high period and more saline varieties during the AMOC low. During the AMOC high there are actually two shorter periods of particularly fresh LSLW, with a more saline variety around 2006. The influx of the freshest LSLW to the Western
Slope Sea therefore occurs episodically. After 2009, the LSLW shows a gradual salinification up until 2013-2014, indicating a slowly reducing input of the fresher waters from the northeast. Also, in most of the occupations, the freshest LSLW occurs intermittently across the North-West Recirculation Gyre, as already noted for May 2008.

Figure 4(a) shows the mean density structure for the AMOC high and low periods. The downward slope of the isopycnals between 38.5 and $36.5^{\circ} \mathrm{N}$ shows the Gulf Stream core, and the LSLW layer is shown shaded, together with the locations of the freshest occurrences in May 2008. The LSLW layer descends from 400 to $600 \mathrm{~m}$ on the northern side of the Gulf Stream, to 1000-1200 m on its southern side. It is always thickest near the slope and decreases in thickness to $38^{\circ} \mathrm{N}$, after which it does not vary greatly, figure 4(b). At station 7, the LSLW increases from $220 \mathrm{~m}$ thickness at AMOC low, to $250 \mathrm{~m}$ at AMOC high, and this forces all the lighter isopycnals to shallow similarly (figures 4(a) and 3(c)). During 

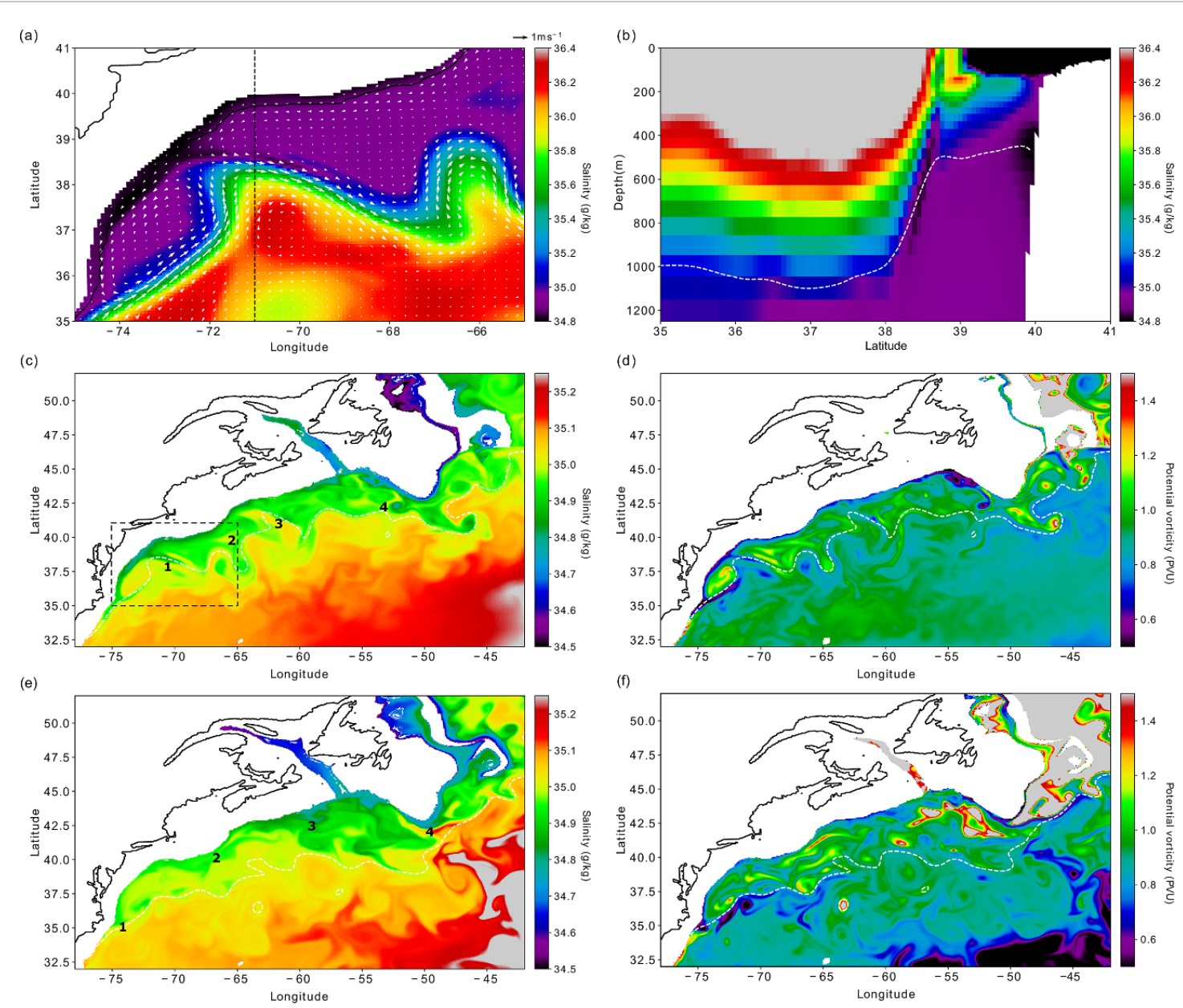

Figure 5. NEMO ocean model $5 \mathrm{~d}$ means centred on January 23 in year 2 of the integration ((a) to (d)). (a) Salinity (colour) and currents (arrows, shown every third gridpoint, $1 \mathrm{~m} \mathrm{~s}^{-1}$ scale arrow at top right) at $565 \mathrm{~m}$ northeast of Cape Hatteras. The black dashed line is drawn at $71^{\circ} \mathrm{W}$. (b) Salinity at $71^{\circ} \mathrm{W}$, also showing the $27.55 \mathrm{~kg} \mathrm{~m}^{-3}$ density contour (white dashed line).

(c) Salinity over a larger area than in (a) and averaged over the $27.5-27.6 \mathrm{~kg} \mathrm{~m}^{-3}$ layer, also showing the position at which the average layer depth is at $700 \mathrm{~m}$ (white dashed line, taken as the Gulf Stream core here), and multiple ejection events 1-4. Note that event 2 leaves the slope near $67^{\circ} \mathrm{W}$ and moves north-eastwards. The black dashed box is the area shown in (a). (d) Similar to (c) but showing full potential vorticity in PV units (PVU) where $1 \mathrm{PVU}=10^{-7} \mathrm{~kg} \mathrm{~m}^{-4} \mathrm{~s}^{-1}$. (e) and (f) are similar to (c) and (d) respectively, but show the salinity and potential vorticity centred on January 23 in year 33 of the integration, and as averages over the $27.4-27.5 \mathrm{~kg} \mathrm{~m}^{-3}$ layer, with the white lines indicating the position at which the average layer depth is at $500 \mathrm{~m}$. Note that multiple ejection events $1-4$ are again shown in (e) and that a uniform value of 0.5 PVU was subtracted from the PV field in (f). The white areas north of the Grand Banks in panels (c) to (f) result from the isopycnal layer in question outcropping at the sea surface.

the AMOC high, the LSLW is also markedly fresher from the slope to $38.5^{\circ} \mathrm{N}$, with diminishing effect across the gyre, figure $4(\mathrm{c})$. This, together with the decreasing thickness across the gyre, is indicative (in the mean) of a source of thick and fresh LSLW on the upper slopes, and spreading across the entire Slope Sea. A plausible explanation for this and the intermittency of the LSLW in individual occupations is LSLW filaments being drawn out of the boundary current by Gulf Stream meanders or eddies and then mixed isopycnally within the gyre.

Figures 4(d) and (e) are similar to figures 4(b) and (c) but now show averages over three fresh full-length occupations in the AMOC high period, and three fulllength saline occupations in the AMOC low (see the blue and red circles, respectively, in figure $3(\mathrm{e})$ ). The effects previously described are increased dramatically with the fresh sections being markedly fresher and thicker between 39 and $40^{\circ} \mathrm{N}$ than the mean of the AMOC high period. This correlation is investigated further in the supplementary material.

\section{Ejection of filaments}

In the NEMO simulation, the LSLW, present in the initial state, flows southwestwards along the slope towards Cape Hatteras and quickly forms filaments which are pulled out into the Slope Sea. Figure 5(a) shows one such event in the Western Slope Sea at the start of the second year of integration at $565 \mathrm{~m}$. An extrusion has formed between 73 and $69^{\circ} \mathrm{W}$ near $38.5^{\circ} \mathrm{N}$ (see the black shades) through interaction with a Gulf Stream meander which has an eastward flow. Figure $5(\mathrm{~b})$ at $71^{\circ} \mathrm{W}$ shows that the filament extends deeply to $1000 \mathrm{~m}$ as it meets the Gulf Stream core at $38.5^{\circ} \mathrm{N}$. The two are interacting strongly, with 
the filament providing fresh and dense water into the system, and being associated with the steep rise in the $27.55 \mathrm{~kg} \mathrm{~m}^{-3}$ isopycnal. The similarity with the irregular occurrences of the LSLW at Line W suggests these filaments are a plausible mechanism to explain the observations.

In the supplementary material, a sequence of events centred on that shown in figure $5(\mathrm{a})$ is examined. There we see how 'upward/downward' dipoles are co-located with northward/southward (or 'coldward/warmward') motion in the meanders, as highlighted in previous studies with simpler models (e.g. Gill 1982, Flierl and Davis 1993). An idealised model is also described which suggests that these dipoles are solidly rooted in quasi-geostrophic dynamics. The ejection event here is thus interpreted as the southeastward and downward entrainment of a fresh slope-origin water mass in the 'warmward' sector of a Gulf Stream meander. The deep extent of this motion is striking, with the filament descending (see figure S3(b)) into and under the Gulf Stream, reflecting the similar occurrence at Line $\mathrm{W}$ in figure 4(a).

Figure 5(c) presents salinity on the LSLW density surface (averaged over the $27.5-27.6 \mathrm{~kg} \mathrm{~m}^{-3}$ layer) over a wider area. The LC is the fresh boundary current extending around the TGB, and providing the source for the LSLW as it continues through the entire Slope Sea (with generally increasing salinity). We identify four concurrent ejection events, all transporting fresh LSLW away from the slope, and caused by interaction of Gulf Stream meanders or eddies with the boundary current as in figure 5(a) (which is event number 1 here). These extrusions reduce the salinity of the entire Slope Sea as far as the Gulf Stream (dashed white line). Figure 5(d) shows the full potential vorticity (PV) for this layer. (PV is essentially inverse layer thickness, modified by the inclusion of all the relative vorticity terms relevant in NEMO, see White et al 2005, and in the absence of mixing this is conserved following the circulation). The LSLW on the slope is a region of generally low PV (being somewhat thicker here) and the extrusions carry this low PV water into the interior of the Slope Sea, acting to reduce the PV there, as well as its salinity. The region of low PV on the western side of the TGB could indicate a possible source of the LSLW in the Slope Sea (through mixing either with topography, or with Gulf Stream eddies which in NEMO propagate northwestwards here, as indicated in figure 1). A further low PV region penetrates to Cape Hatteras and retroflects to the northeast, possibly affecting Gulf Stream separation. These features require further investigation.

To contrast model differences between AMOC high and low states, figures 5(e) and (f) are similar to panels (c) and (d) but show the situation in January of year 33 (the final year) of the integration rather than in year 2, when the AMOC (at $26.5^{\circ} \mathrm{N}$ ) has reduced from 13.2 Sv (in January of year 2) to $7.4 \mathrm{~Sv}$. The LSLW is still found as a salinity minimum on the shelf slopes in the Slope Sea, but with a core on a slightly lighter density surface, $27.45 \mathrm{~kg} \mathrm{~m}^{-3}$ rather than $27.55 \mathrm{~kg}^{-3}$, so that figures $5(\mathrm{e})$ and (f) are representative of this change. The LSLW still appears as a low salinity, low PV boundary current extending to, and retroflecting at, Cape Hatteras, and filaments of the LSLW, comprising this low salinity, low PV water, are still apparent (marked as 1-4) being drawn out from the boundary current, though perhaps marginally less well pronounced than in year 2 . This may be because the Gulf Stream meanders (indicated by the white dashed lines) are further from the slopes at this time. We also remark that while a full investigation is beyond the scope of the present study, a comparison of these two snapshots does show fresher and thicker (lower PV) LSLW in the Western Slope Sea when the AMOC is higher (especially noting that a uniform value of 0.5 PVU has been subtracted in panel (f)), in agreement with the observational results above.

\section{Summary and discussion}

LSLW (of densities $27.4-27.65 \mathrm{~kg} \mathrm{~m}^{-3}$ ) has its origins on the Labrador shelf in the subarctic, and in the Slope Sea is an intermediate depth water mass above the LSW. We have shown that the LSLW penetrates deeply into the Western Slope Sea as a boundary current where it is characterised by a salinity minimum between 400 and $600 \mathrm{~m}$ on the slopes, and where it interacts strongly with the Gulf Stream. The LSLW is relatively thick and fresh during the recent AMOC high period (2003-08), compared with the following AMOC low period (2009-14). This thickening lifts up the isopycnals in the upper $600 \mathrm{~m}$ on the slope, and increases the density gradient across the Gulf Stream, contributing an additional $1.3 \mathrm{~Sv}$ to its transport. The LSLW is also drawn out from the boundary current in extrusions, caused by Gulf Stream meanders or eddies, bringing fresher and lower PV water to the whole Slope Sea in this density layer.

Our study has focussed on the impacts of the LSLW in the Western Slope Sea. However, it is clear that periods of thicker LSLW propagate along the shelf-slope and must first transit the Eastern Slope Sea. Given that there is no additional source of the LSLW along this pathway, we would expect the impact of the LSLW on the Gulf Stream transport and AMOC here to be just as large as in the Western Slope Sea, and possibly even larger given that the continued mixing away from the boundary in the filaments as the LSLW travels southwestwards would tend to lessen the LSLW thickening with distance travelled, and hence its impact on the AMOC. However, as there are no observations similar to Line W in the Eastern Slope Sea, we are unable to investigate this aspect further here.

It has long been known that the Gulf Stream position is affected by the (winter) NAO, the prin- 
cipal mode of atmospheric variability in the North Atlantic) index, with a high NAO being associated with a northerly position of the Gulf Stream, with a lag of either 2 years (Taylor and Stephens 1998) or occurring simultaneously (Joyce et al 2000). In particular, the Icelandic Low component of the NAO is likely to have a dominant influence over the position of the Gulf Stream, in contrast to the Azores High, suggesting variability in the transport of waters from the Labrador region into the Slope Sea provides the important control over the Gulf Stream position (Sanchez-Franks et al 2016). The connection between the NAO and the Gulf Stream is apparent in figure 4, in that the Gulf Stream at Line W is further north during 2003-2008 than during 2009-2014 (the $26.6 \mathrm{~kg} \mathrm{~m}^{-3}$ isopycnal at $200 \mathrm{~m}$, close to the $15^{\circ} \mathrm{C}$ isotherm, moving from 38.4 to $38.0^{\circ} \mathrm{N}$ between these periods), together with the observation that the $\mathrm{NAO}$ is neutral during the former period and negative during the latter (Robson et al 2018). We also note in figure 4 the increased thickening between the density surfaces $26.2-26.6 \mathrm{~kg} \mathrm{~m}^{-3}$ between 34 and $36.5^{\circ} \mathrm{N}$ during the AMOC high, implying lower PV in the Subtropical Mode Water when the Gulf Stream is further north. Although this is counter to the finding of Joyce et al (2000), their result describes the PV changes near Bermuda $\left(33^{\circ} \mathrm{N}\right)$ and at $300 \mathrm{~m}$ depth.

The realisation that the NAO and Gulf Stream position co-vary led Joyce et al (2000) to propose a mechanism for decadal climate variability in the North Atlantic. When the NAO is high, the winds in the subpolar gyre are strong, leading to enhanced cooling and open ocean convection in the Labrador Sea. This produces an enhanced southward flow of the LSW which is entrained into the DWBC and transported along the slopes to the Gulf Stream separation region. Here, the two currents interact, with the DWBC passing below the Gulf Stream, but with the additional LSW pushing the Gulf Stream into a more southerly position. This southward movement would, through changes in the sea-surface temperature and air-sea fluxes, then cause a reduction in the $\mathrm{NAO}$ (as these are observed to co-vary), resulting in a lessening of LSW production and a reversal of the cycle. This was shown by Joyce et al (2000) to lead to cycles on the decadal timescale.

Other mechanisms affecting decadal variability have been proposed which involve changes in the Gulf Stream transport rather than its position. Robson et al (2014) proposed that increases in the LSW density would propagate along the western boundary and act to increase the east-west density gradient across the Gulf Stream, increasing its transport and the AMOC. The subsequent increased northward heat transport would warm the subpolar gyre, causing a reduction of the LSW density and a reversal of the cycle. Similarly, Menary et al (2015) described several modelling studies which involved variations in the LSW leading to deep anomalies propagating along the western boundary, and then to subsequent changes in the northward ocean circulation and heat transport, leading finally to changes in the Labrador Sea and a reversal of the cycle. In these studies, a positive feedback was also often found to occur between the $\mathrm{NAO}$ and the sea-surface temperatures in the subpolar gyre which amplified the mode. Depending on the model studied, cycles arose with timescales of between 10 and 50 years.

We now address the question as to whether the LSLW could play a similar role in decadal cycling in the North Atlantic as outlined above for the deeper LSW, remembering that observations do not strongly support such a role for the LSW. Firstly, we remark that we have established here a strong presence of the LSLW throughout the Slope Sea. Secondly, temperature-salinity analysis (Petrie and Drinkwater 1993) clearly shows that the LSLW derives its cold, fresh properties from the Labrador Current on the Labrador and Newfoundland Shelves. There is therefore a direct observational connection for the LSLW between these two regions (supported by the model results in figure 5).

Peterson et al (2017) then suggest that a stronger flow of LC water westwards from the TGB is caused by a southward shift of the Zero Wind stress Curl Line (ZWCL) near $40^{\circ} \mathrm{W}$ (and $40^{\circ} \mathrm{N}$ ), whereas the Gulf Stream position is instead related to wind stress changes linked to the NAO further to the northeast. They also invoke such an enhanced LC inflow to explain a cooling event in the upper $650 \mathrm{~m}$ on the Nova Scotia shelf and slope between 2004 and 2009 , and relate this to a more southerly position of the Shelf Slope Front rather than to any shift in the Gulf Stream. Figure 6 shows that the Shelf Slope Front in our study, denoted by the offshore boundary of the fresh Coastal Water in the upper layer (with salinity below 35.4), is indeed further southwards (and extends more deeply) when the LSLW is fresher between 2003 and 2008 than during 2009-14. This both supports the conclusion of Peterson et al (2017), and shows that the Shelf Slope Front is further south at the same time as the LSLW is fresher. Indeed, Peña-Molino and Joyce (2008) find that fresher and cooler water occur in phase, together with enhanced south-westward flow, in the upper 1000-1500 m over the slopes at Line W during 2003-2006. We conclude that enhanced inflows of LC water into the Slope Sea would simultaneously feed both the Shelf Break Jet and thereby enhanced volumes of Coastal Water spilling southwards into the Shelf Slope Front, and the LSLW, causing them both to experience cooling and freshening concurrently.

Similarly, Holliday et al (2020) propose a windstress induced alternation between freshening events west of the TGB, and in the eastern North Atlantic, depending on whether the $\mathrm{LC}$ is steered more strongly to the southwest or to the east at the Grand Banks. They analyse wind stress patterns from the 


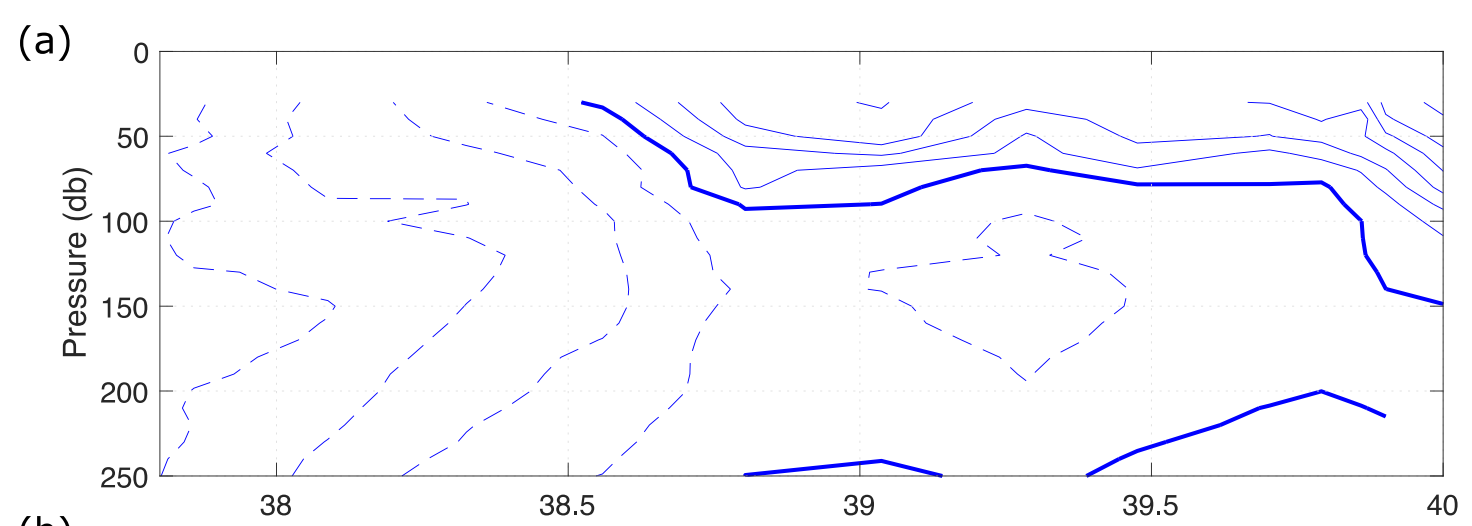

(b)

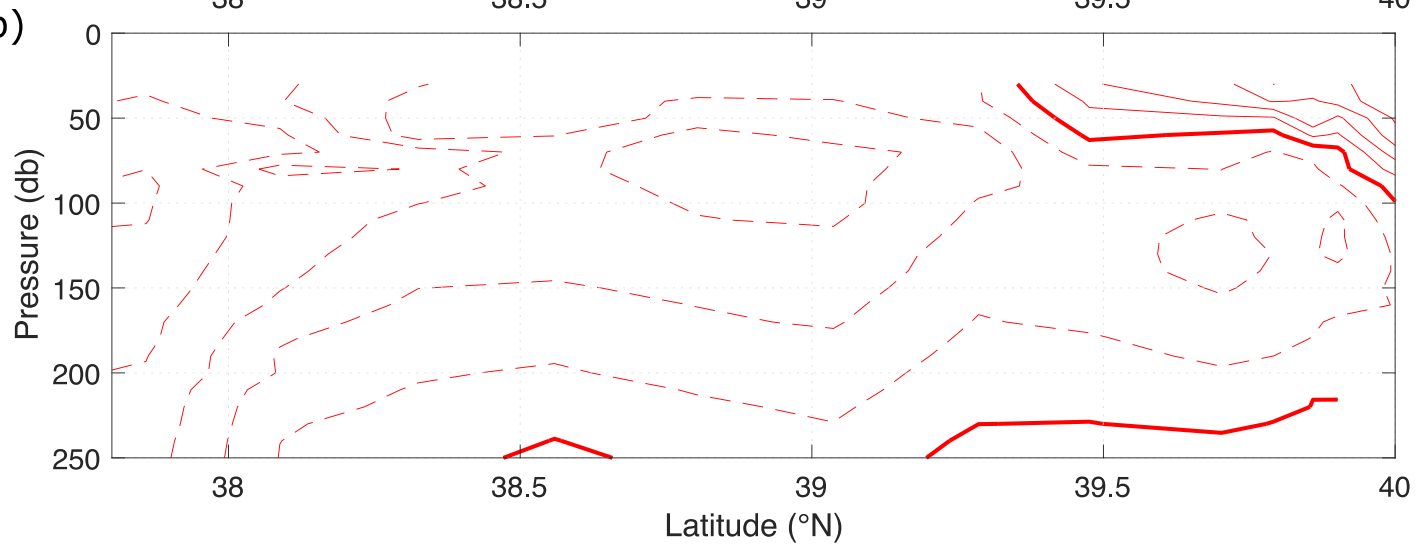

Figure 6. Mean salinity (plotted against depth in db) during the (a) AMOC high (blue) and (b) AMOC low (red) periods. Continuous contours denote water from and fresher than 35.4, and dashed contours show water saltier than 35.4. The 35.4 contour is shown as the thick continuous line and the contour interval is 0.2 . Data is plotted from $30 \mathrm{db}$ as there is significant seasonal variability above this depth which is not adequately resolved in the AMOC low period.

ERA-interim dataset, and show a switch from positive to negative wind stress curl in the Newfoundland shelf region (just north of the Grand Banks) from about 2012, associated with a northward shift of the ZWCL here, leading to a greater transport of LC waters off the shelf (due to enhanced Ekman transport) and into the northeast Atlantic. At the same time, there is correspondingly less LC water flowing into the Slope Sea, leading to an increased (upper layer) salinity there.

The key aspect in both Peterson et al (2017) and Holliday et al (2020) therefore seems to be whether the ZWCL is northwards or southwards of the Grand Banks region. We examine this further in figure 7 . Figure 7 (a) shows the mean wind stress curl between 1982 and 2020 in the ERA5 dataset, with a generally positive region in the subpolar gyre (north of about $48^{\circ} \mathrm{N}$ ), and a negative region further south. Figure 7 (b) then shows wind stress curl time-series in two key regions near the Grand Banks, these being directly over the Flemish Pass (the channel between the Flemish Cap and the Grand Banks through which the LC flows), and on the Newfoundland shelf just to the north. Between 2002 and 2010, the mean curl over the Newfoundland region is positive, but this then reduces rapidly between 2010 and 2012, becoming negative between 2012 and 2018. In the Flemish Pass region, the wind curl is close to zero in the former period, and strongly negative in the latter. It is clear that the ZWCL has moved north between these two regions, between 2010 and 2012, with a region of negative curl extending further northwards along the Newfoundland shelf. From the above studies, this would be expected to reduce or terminate the flow of the fresh LC water into the Slope Sea between these times.

Consistent with these ideas (since ocean currents tend to follow the ZWCL line e.g. Marshall et al 2001), Gonçalves Neto et al (2021) find north-south shifts of the Gulf Stream near the TGB between 2008 and 2010, with a final northward shift occurring by 2011-2012, and that such northward shifts are accompanied by warming on the Scotian Shelf and Slope about a year later. They argue that the northward shift of the Gulf Stream acts to reduce the inflow of the LC waters into the Slope Sea, so causing the observed warming. They also show that the LSLW at the TGB becomes saltier and warmer at about the same time. In addition, a reduced inflow of the LSLW into the Slope Sea from about 2010 is consistent with Andres et al (2020) who show that the North-West and Northern Recirculation Gyres are stronger and better connected during 2004-08 than during 2010-14.

In terms of propagation timescales, Peterson et al (2017) obtain maximum correlations between the year-to-year changes in the Shelf Slope Front position and the wind curl (near $40^{\circ} \mathrm{W}$ ) using a lag of 


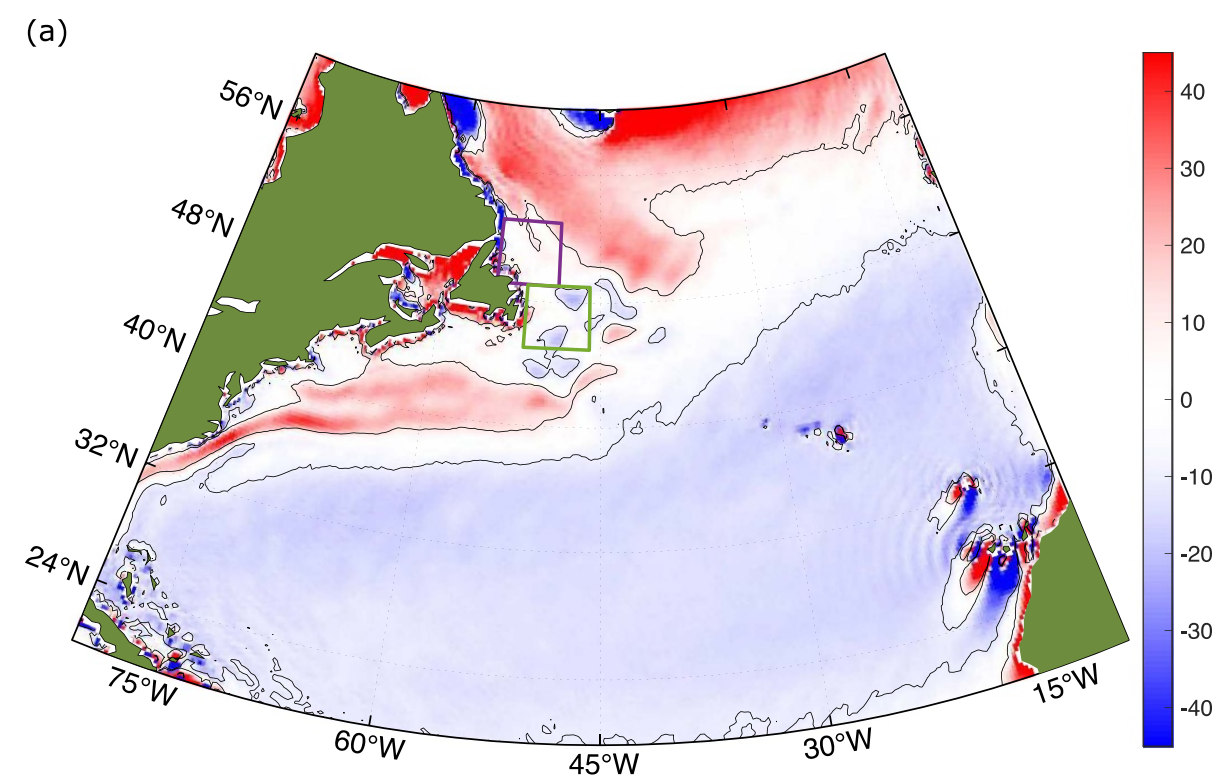

(b)

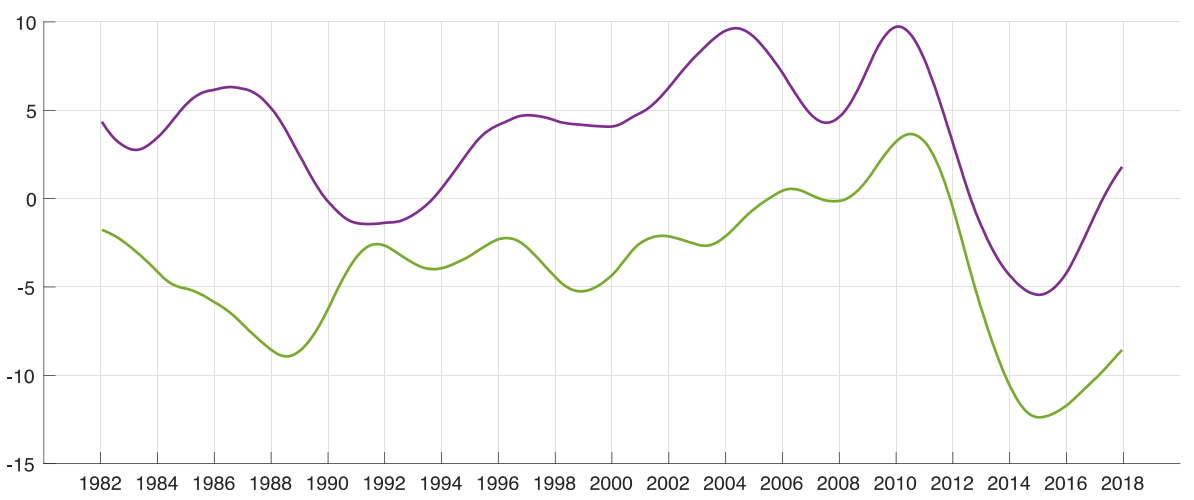

Figure 7. (a) Mean wind stress curl $\left(\mathrm{N} \mathrm{m}^{-3}\right)$ between 1982 and 2020 from the ERA5 dataset. Boxes for the Flemish Pass (green) and Newfoundland Shelf (purple) regions are shown, and thin black lines indicate the positions of the +10 and $-10 \mathrm{~N} \mathrm{~m}^{-3}$ contours. (b) Time series of wind stress curl $\left(\mathrm{N} \mathrm{m}^{-3}\right)$ as averages over the Flemish Pass (green) and Newfoundland Shelf (purple) regions (to which a 6 year time filter has been applied).

8 months. This is consistent with the 4-6 month timescale found by Peña-Molino and Joyce (2008) for sea-surface temperature anomalies to propagate from 60 to $75^{\circ} \mathrm{W}$ in the Slope Sea, and with an examination of the model in section 5 , which shows that LSLW anomalies would take 9-12 months to travel from the Newfoundland Shelf to the Gulf Stream separation region. Furthermore, Gonçalves Neto et al (2021) found that the propagation of surface velocity anomalies from the TGB to $67^{\circ} \mathrm{W}$ takes about 10 months.

Finally, we remark that the expected reduction or termination of the flow of the fresh LC water into the Slope Sea from about 2010-2012 and the likely timescale of 10-12 months for changes to propagate between the Newfoundland Shelf and the Slope Sea, are completely consistent with the freshest LSLW at Line W (figure 3) occurring between 2003 and 2009, with the subsequent gradual salinification between 2010 and 2012, and with the most saline varieties occurring in 2013-2014 (indicating a possible cessation of the LSLW inflows then).
We therefore propose the LSLW transport as a new mechanism for connecting changes on the Labrador and Newfoundland Shelves in the subarctic with the Gulf Stream, and that such a connection is favoured when the ZWCL near the Grand Banks is sufficiently far southwards. This would allow an enhanced flow of the LC into the Slope Sea, leading to thicker and fresher LSLW, and an increased Gulf Stream transport and AMOC, about 10-12 months later. Further analysis of our model results also shows the Gulf Stream being pushed southwards into a good separation position just eastwards of Cape Hatteras when sufficient quantities of the LSLW reach this point. The increased flows of the LSLW could therefore result in either or both an increased Gulf Stream transport or a more southerly Gulf Stream position, and thereby take part in mechanisms similar to those proposed by either Joyce et al (2000), Robson et al (2014) or Menary et al (2015), but which rely instead on the deeper LSW. A full investigation of these ideas will be undertaken as a separate study in a very high-resolution climate model 
with an ocean resolution similar to that used here $(7.5 \mathrm{~km})$, capable of resolving the processes involved (the models in the studies above using ocean resolutions of at best $25 \mathrm{~km}$, insufficient to resolve such processes).

In summary, the LSLW, deriving its properties from the Labrador Current, itself influenced by flows from the Arctic through the Davis Strait, could therefore provide a new and alternative pathway (supported by observations) for connecting the subarctic with the Gulf Stream, and offer a potential new mechanism for decadal variability. It is now more important than ever to better understand such pathways and mechanisms, since enhanced future outflows of freshwater from the Arctic (particularly through the Canadian Arctic Archipelago into the Davis Strait) are likely to further freshen the Labrador Current and reduce the AMOC (Gervais et al 2018).

\section{Data availability statement}

The data that support the findings of this study are openly available at the following URL/DOI: https:// scienceweb.whoi.edu/linew/index.php.

\section{Acknowledgments}

This research was supported by the UK Natural Environment Research Council ACSIS (Grant NE/N018044/1) and RAPID-AMOC programmes, and by the European Union's Horizon 2020 research and innovation programme COMFORT (Grant Agreement No. 820989). The EN4.2.1 dataset is available from www.metoffice.gov.uk/hadobs/ en4/, the Line W observations from https:// scienceweb.whoi.edu/linew/index.php, and the ERA5 dataset from https://cds.climate.copernicus.eu/ cdsapp\#!/dataset/reanalysis-era5-single-levels-mont

hly-means? The NEMO model output is available from the authors upon reasonable request. We also thank Bablu Sinha and two anonymous reviewers for helpful discussions and comments on the manuscript, and Tess, Hatty and Karen for their support during the preparation of this work.

\section{Disclaimer}

This work reflects only the authors' views. The European Commission and their executive agency are not responsible for any use that may be made of the information this work contains.

\section{ORCID iDs}

A L New (1) https://orcid.org/0000-0002-3159-8872

D A Smeed (ㄱ https://orcid.org/0000-0003-1740-

1778

A Czaja (1) https://orcid.org/0000-0003-3645-0284
A T Blaker (1) https://orcid.org/0000-0001-54540131

J V Mecking (1) https://orcid.org/0000-0002-18341845

J P Mathews (1) https://orcid.org/0000-0003-18532147

A Sanchez-Franks (i) https://orcid.org/0000-00024831-5461

\section{References}

Andres M K, Donohue A and Toole J M 2020 The Gulf Stream's path and time-averaged velocity structure and transport at 68.5 ${ }^{\circ} \mathrm{W}$ and $70.3^{\circ} \mathrm{W}$ Deep-Sea Res. I 156103179

Antonov J I, Locarnini R A, Boyer T P, Mishonov A V and Garcia H E 2006 World Ocean Atlas 2005, Volume 2: Salinity ed S Levitus (Washington, DC: NOAA Atlas NESDIS, U.S. Government Printing Office) p 182

Bower A S, Lozier M S, Gary S F and Böning C W 2009 Interior pathways of the North Atlantic meridional overturning circulation Nature 459 243-7

Bower A, Lozier S and Gary S 2011 Export of Labrador Sea Water from the subpolar North Atlantic: a Lagrangian perspective Deep-Sea Res. II 58 1798-818

Brodeau L, Barnier B, Treguier A M, Penduff T and Gulev S 2010 An ERA40-based atmospheric forcing for global ocean circulation models Ocean. Modell. 31 88-104

Claret M, Galbraith E D, Palter J B, Bianchi D, Fennel K, Gilbert D and Dunne J P 2018 Rapid coastal deoxygenation due to ocean circulation shift in the northwest Atlantic Nat. Clim. Change 8 868-72

Csanady G T and Hamilton P 1988 Circulation of slopewater Cont. Shelf Res. 8 565-624

Flagg C N, Dunn M, Wang D P, Rossby H T and Benway R L 2006 A study of the currents of the outer shelf and upper slope from a decade of shipboard ADCP observations in the Middle Atlantic Bight J. Geophys. Res. $111 \mathrm{C} 06003$

Flierl G and Davis C 1993 Biological effects of Gulf Stream meandering J. Mar. Res. 51 529-60

Florindo-López C, Bacon S, Aksenov Y, Chafik L, Colbourne E and Holliday N P 2020 Arctic ocean and hudson bay freshwater exports: new estimates from seven decades of hydrographic surveys on the labrador shelf J. Clim. 33 8849-68

Fratantoni P S and Pickart R S 2007 The Western North atlantic shelfbreak current system in summer J. Phys. Oceanogr. 37 2509-33

Gary S F, Lozier M S, Böning C W and Biastoch A 2011 Deciphering the pathways for the deep limb of the meridional overturning circulation Deep-Sea Res. II 58 1781-97

Gatien M G 1976 A study in the slope water region south of halifax J. Fish. Board Can. 33 2213-7

Gervais M, Shaman J and Kushnir Y 2018 Mechanisms governing the development of the north atlantic warming hole in the CESM-LE future climate simulations J. Clim. 31 5927-46

Gill A E 1982 Atmosphere-Ocean Dynamics (New York: Academic) p 662

Gonçalves Neto A, Langan J A and Palter J B 2021 Changes in the Gulf Stream preceded rapid warming of the Northwest Atlantic Shelf Commun. Earth Environ. 274

Good S A, Martin M J and Rayner N A 2013 EN4: quality controlled ocean temperature and salinity profiles and monthly objective analyses with uncertainty estimates $J$. Geophys. Res. Oceans 118 6704-16

Hersbach $\mathrm{H}$ et al 2019 ERA5 monthly averaged data on single levels from 1979 to present Copernicus Climate Change Service (C3S) Climate Data Store (CDS) (https://doi.org/ 10.24381/cds.f17050d7) 
Hogg N G, Pickart R S, Hendry R M and Smethie W J 1986 The northern recirculation gyre of the Gulf Stream Deep-Sea Res. I 33 1139-65

Holliday N P et al 2020 Ocean circulation causes the largest freshening event for 120 years in eastern subpolar North Atlantic Nat. Commun. 11585

Joyce T M, Deser C and Spall M A 2000 The relation between decadal variability of subtropical mode water and the North Atlantic Oscillation J. Clim. 13 2550-69

Joyce T M, Dunworth-Baker J, Pickart R S, Torres D and Waterman S 2005 On the Deep Western Boundary Current south of cape cod Deep-Sea Res. II 52 615-25

Levitus S 1982 Climatological atlas of the world ocean NOAA/ERL GFDL, Professional Paper 13 (Princeton, NJ) p 173 (NTIS PB83-184093)

Locarnini R A, Mishonov A V, Antonov J I, Boyer T P and Garcia H E 2006 World Ocean Atlas 2005, Volume 1: Temperature ed S Levitus (Washington, DC: NOAA Atlas NESDIS 61, U.S. Government Printing Office) p 182

Lozier M S, McCartney M S and Owens W B 1994 Anomalous anomalies in averaged hydrographic data J. Phys. Oceanogr. $242624-38$

Madec G 2008 NEMO ocean engine Note du Pole de modelisation 27 (Institut Pierre-Simon Laplace) p 209

Marsh R 2000 Modelling changes in North Atlantic circulation under the NAO-minimum wind forcing of 1877-81 Atmos. Ocean 38 367-93

Marshall J, Johnson H and Goodman J 2001 A study of the interaction of the North Atlantic Oscillation with ocean circulation J. Clim. 14 1399-421

Marzocchi A, Hirschi J J M, Holliday N P, Cunningham S A, Blaker A T and Coward A C 2015 The North Atlantic subpolar circulation in an eddy-resolving global ocean model J. Mar. Sys. 142 126-43

McCartney M S and Talley L D 1982 The subpolar mode water of the North Atlantic ocean J. Phys. Oceanogr. 12 1169-88

Menary M B, Hodson D L R, Robson J I, Sutton R T and Wood R A 2015 A mechanism of internal decadal atlantic ocean variability in a high-resolution coupled climate model J. Clim. 28 7764-85

Mountain D G 2012 Labrador slope water entering the gulf of maine-response to the North Atlantic Oscillation Cont. Shelf Res. 47 150-5

Peña-Molino B and Joyce T M 2008 Variability in the slope water and its relation to the Gulf Stream path Geophys. Res. Lett. 35 L03606

Peña-Molino B, Joyce T M and Toole J M 2011 Recent changes in the Labrador Sea Water within the Deep Western Boundary Current southeast of cape cod Deep-Sea Res. I 58 1019-30

Peterson I, Greenan B, Gilbert D and Hebert D 2017 Variability and wind forcing of ocean temperature and thermal fronts in the Slope Water region of the Northwest Atlantic J. Geophys. Res. Oceans 122 7325-43

Petrie B and Drinkwater K 1993 Temperature and salinity variability on the Scotian Shelf and in the Gulf of Maine 1945-1990 J. Geophys. Res. Oceans 98 20079-89

Richardson P L 1977 On the crossover between the Gulf Stream and the western boundary undercurrent Deep-Sea Res. 24 139-59
Robson J et al 2018 Recent multivariate changes in the North Atlantic climate system, with a focus on 2005-2016 Int. J. Climatol. 38 5050-76

Robson J, Hodson D, Hawkins E and Sutton R 2014 Atlantic overturning in decline? Nat. Geosci. 7 2-3

Rossby T 1999 On gyre interactions Deep-Sea Res. II 46 139-64

Saba V S et al 2016 Enhanced warming of the Northwest Atlantic Ocean under climate change J. Geophys. Res. Oceans $121118-32$

Sanchez-Franks A, Hameed S and Wilson R E 2016 The Icelandic Low as a predictor of the Gulf stream north wall position $J$. Phys. Oceanogr. 46 817-26

Sanchez-Franks A and Zhang R 2015 Impact of the Atlantic meridional overturning circulation on the decadal variability of the Gulf Stream path and regional chlorophyll and nutrient concentrations Geophys. Res. Lett. 42 9889-97

Smeed D A et al 2018 The North Atlantic Ocean is in a state of reduced overturning Geophys. Res. Lett. 45 1527-33

Smith J N, Smethie W M Jr, Yashayev I, Curry R and Azetsu-Scott K 2016 Time series measurements of transient tracers and tracer-derived transport in the deep western boundary current between the labrador sea and the subtropical atlantic ocean at line W J. Geophys. Res. Oceans $1218115-38$

Talley L D and McCartney M S 1982 Distribution and circulation of Labrador Sea Water J. Phys. Oceanogr. 12 1189-205

Taylor A H and Stephens J A 1998 The North Atlantic Oscillation and the latitude of the Gulf Stream Tellus 50A 134-42

Thibodeau B et al 2018 Last century warming over the Canadian Atlantic shelves linked to weak Atlantic meridional overturning circulation Geophys. Res. Lett. 45 376-85

Toole J M, Curry R G, Joyce T M, McCartney M and Peña-Molino B 2011 Transport of the North Atlantic deep western boundary current about $39^{\circ} \mathrm{N}, 70^{\circ} \mathrm{W}: 2004-2008$ Deep-Sea Res. II 58 1768-80

Townsend D W, Pettigrew N R, Thomas M A, Neary M G, McGillicuddy D J Jr. and O’Donnell J 2015 Water masses and nutrient sources to the Gulf of Maine J. Mar. Res. 73 93-122

U.S. Department of Commerce 2006 U.S. department of commerce, national oceanic and atmospheric administration, national geophysical data center: 2-minute gridded global relief data (ETOPO2v2) (available at: www.ngdc.noaa.gov/mgg/global/etopo2.html) (Accessed 10 January 2013)

Watts D R 1991 Equatorward currents in temperatures $1.8^{\circ} \mathrm{C}-6.0^{\circ} \mathrm{C}$ on the continental slope in the mid-atlantic bight Deep Convection and Deep Water Formation in the Oceans ed P C Chu and J C Gascard (Amsterdam: Elsevier) pp 183-96

White A A, Hoskins B J, Roulstone I and Staniforth A 2005 Consistent approximate models of the global atmosphere: shallow, deep, hydrostatic, quasi-hydrostatic and non-hydrostatic Q. J. R. Meteorolog. Soc. 131 2081-107

Zhang R and Vallis G K 2007 The role of bottom vortex stretching on the path of the North Atlantic western boundary current and on the northern recirculation gyre J. Phys. Oceanogr. 37 2053-80 